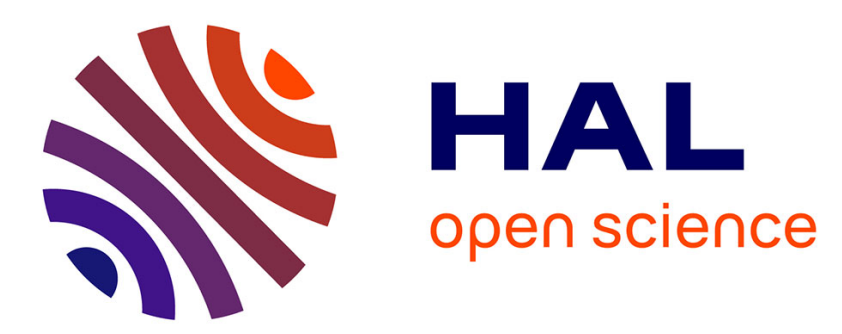

\title{
A Mw 6.3 earthquake scenario in the city of Nice (southeast France): ground motion simulations
}

Jérome Salichon, Carine Kohrs-Sansorny, Etienne Bertrand, Françoise

Courboulex

\section{- To cite this version:}

Jérome Salichon, Carine Kohrs-Sansorny, Etienne Bertrand, Françoise Courboulex. A Mw 6.3 earthquake scenario in the city of Nice (southeast France): ground motion simulations. Journal of Seismology, 2009, 14 (3), pp.523-541. 10.1007/s10950-009-9180-0 . hal-00540029

\section{HAL Id: hal-00540029 \\ https://hal.science/hal-00540029}

Submitted on 26 Nov 2010

HAL is a multi-disciplinary open access archive for the deposit and dissemination of scientific research documents, whether they are published or not. The documents may come from teaching and research institutions in France or abroad, or from public or private research centers.
L'archive ouverte pluridisciplinaire HAL, est destinée au dépôt et à la diffusion de documents scientifiques de niveau recherche, publiés ou non, émanant des établissements d'enseignement et de recherche français ou étrangers, des laboratoires publics ou privés. 


\title{
A Mw 6.3 earthquake scenario in the city of Nice (southeast France): ground motion simulations
}

\author{
Jérome Salichon - Carine Kohrs-Sansorny • \\ Etienne Bertrand · Françoise Courboulex
}

Received: 15 February 2009 / Accepted: 2 November 2009 / Published online: 26 November 2009

(C) Springer Science + Business Media B.V. 2009

\begin{abstract}
The southern Alps-Ligurian basin junction is one of the most seismically active zone of the western Europe. A constant microseismicity and moderate size events $(3.5<\mathrm{M}<5)$ are regularly recorded. The last reported historical event took place in February 1887 and reached an estimated magnitude between 6 and 6.5, causing human losses and extensive damages (intensity X, Medvedev-Sponheuer-Karnik). Such an event, occurring nowadays, could have critical consequences given the high density of population living on the French and Italian Riviera. We study the case of an offshore Mw 6.3 earthquake located at the place where two moderate size events (Mw 4.5) occurred recently and where a morphotectonic feature has been detected by a bathymetric survey. We used a stochastic empiri-
\end{abstract}

J. Salichon · C. Kohrs-Sansorny · F. Courboulex

Observatoire de la Côte d'Azur,

Géoazur Nice-Sophia Antipolis University,

CNRS, Nice, France

E. Bertrand

LCPC-CETE Méditerranée, Nice, France

J. Salichon $(\varangle) \cdot$ E. Bertrand $(\varangle) \cdot$ F. Courboulex $(\varangle)$

Géoazur, 250 rue Albert Einstein, Sophia Antipolis,

06560 Valbonne, France

e-mail: salichon@geoazur.unice.fr

e-mail: etienne.bertrand@developpement-durable.gouv.fr

e-mail: courboulex@geoazur.unice.fr cal Green's functions (EGFs) summation method to produce a population of realistic accelerograms on rock and soil sites in the city of Nice. The ground motion simulations are calibrated on a rock site with a set of ground motion prediction equations (GMPEs) in order to estimate a reasonable stress-drop ratio between the February 25th, 2001, Mw 4.5, event taken as an EGF and the target earthquake. Our results show that the combination of the GMPEs and EGF techniques is an interesting tool for site-specific strong ground motion estimation.

Keywords Strong ground motion •

Seismic hazard - Ground motion simulations • Empirical green's functions - Ligurian basin . Alps • Mediterranean Sea

\section{Introduction}

The region of interest is situated in the southeast of France at the junction between the Alps and the Ligurian basin. In this zone, a regular microseismicity is recorded, and every 4 to 5 years, an earthquake with a magnitude larger than 4.5 occurs (Fig. 1). These moderate size events are usually felt by the population but have never caused noticeable damage. However, some destructive earthquakes have struck the region in the past. In 1564, an inland earthquake completely 
Fig. 1 Overview of the Ligurian (Southern Alps) region and the Nice city area. Black filled circles indicate the instrumented seismicity for the period 1988 to 2001 from the Bureau Central Sismologique Français database

(http://www.seisme.prd.fr). Topography and bathymetry is a synthesis of the 50-m database of the Institut Géographique National (www.ign.fr), SRTM 90-m database, IBCM 100-m database, and the IFREMER multifaisceau 2003 database

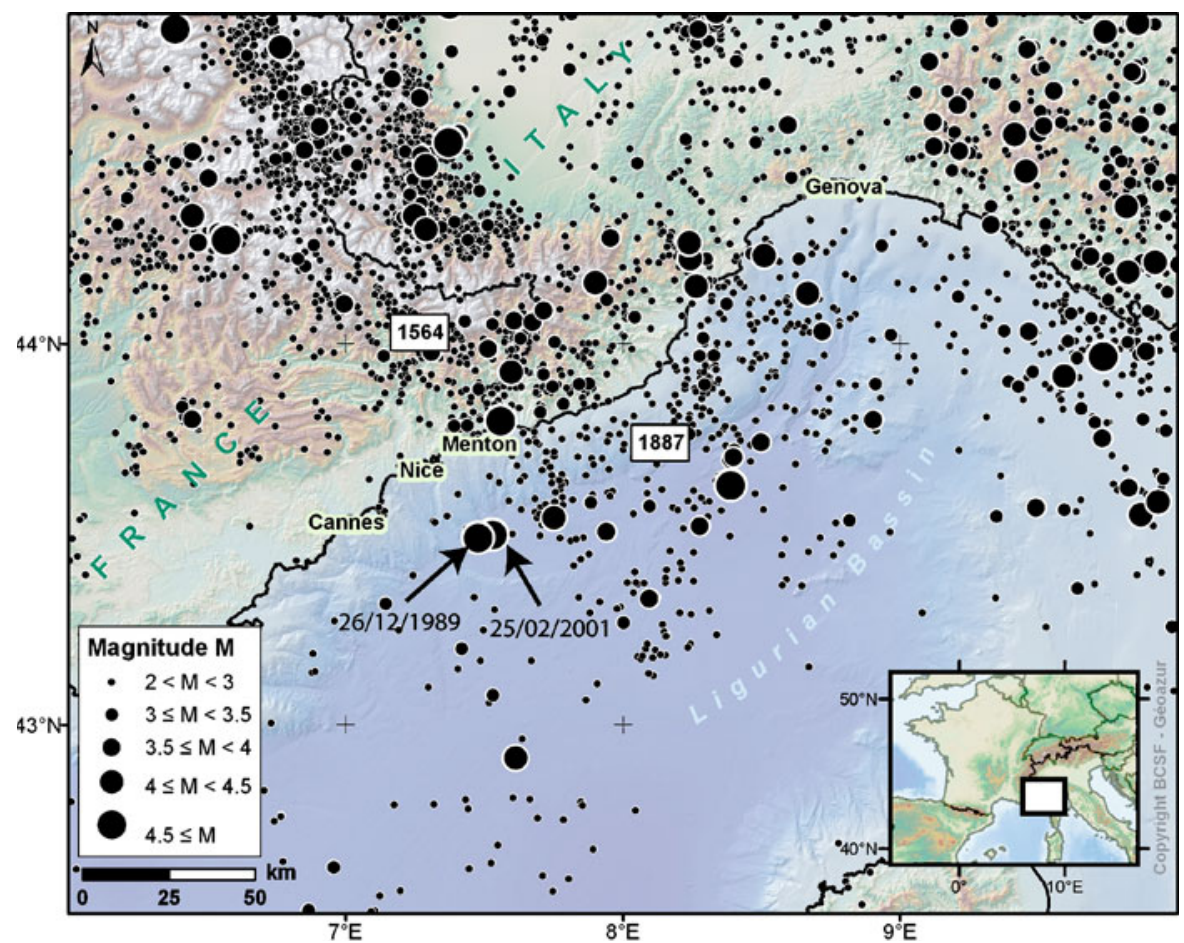

destroyed a village located $50 \mathrm{~km}$ north of Nice and caused several victims (Lambert et al. 1994). More recently, a major earthquake occurred offshore, in the Ligurian Sea, close to the Italian coast. This event on February 1887 reached an intensity of X (Medvedev-Sponheuer-Karnik), caused the death of 600 persons on the Italian coast, and a few casualties on the French coast between Menton and Nice. Its magnitude was estimated to be at least $M=6.3$ (Ferrari 1991; Bakun and Scotti 2006). If such an earthquake were to occur today, it would be more likely to produce more destruction because of the higher population density in the French and Ligurian Riviera (about two million inhabitants). Thus, it is of utmost importance to assess the seismic risk in this region.

Ground motion simulation is a key step in the evaluation of the possible impact of a seismic event in an urban area. Because of this, it is essential in the preparedness for crisis. Local site effects have long been recognized as an important factor contributing to variations in strong ground motion. Therefore, these effects also contribute directly to the distribution of the consequences of a given earthquake over a city.
The strength of shaking at a particular location from an earthquake scenario can be estimated by ground motion prediction equations (GMPEs) fitted to strong-motion data from past earthquakes (see Douglas 2003 for a review). These equations typically include only the most obvious explanatory parameters: magnitude, distance, local site conditions, and sometimes a few others (focal mechanism for example). Nevertheless, the site conditions are often only roughly taken into account. Various approaches have been used, from simple binary rock/soil classifications (e.g., Berge-Thierry et al. 2003) to the explicit use of shear-wave velocity (e.g., Next Generation Attenuation project, Power et al. 2008). However, the simplified evaluation of local seismic responses on soft soil deposits obtained through these approaches may not be accurate. Indeed, they take into account an average soil response that can hardly be representative of particular soil such as very soft soil, very thick soil, or artificial fills. Moreover, topographic effects and, more generally, all the $3 \mathrm{D}$ effects cannot be taken into account.

GMPEs have already been applied to Nice to evaluate the ground motion at rock sites for 
reference earthquakes (e.g., Mouroux et al. 2004). To take into account the local site effect that has been detected in the major part of the city (Duval 1996; Duval et al. 2001), these studies modify the ground motion assessed at the rock site by the use of a numerical 1D soil response simulation (Bard et al. 2005) or simply by the use of the seismic French code soil classification (Stieltjes et al. 1996). These microzonation studies are based on a geotechnical model of the quaternary deposits under the city (Bertrand et al. 2007) and lead in shaking maps over the whole city of Nice. However, the site effects in Nice are known to be influenced by the geometry of the basin (Semblat et al. 2000), and the $1 \mathrm{D}$ simulations do not match the experimental measurements at least in some parts of the city (Régnier et al. 2008; Gélis et al. 2008).

Our work is part of the Quantitative Seismic Hazard Assessment project. This project aims at comparing different 3D wave propagation simulation methods for ground motion evaluation in the Nice, Grenoble, Algiers, and Naples areas with the same input parameters. Most of the methods included the source complexity and the travel path from the source to the surface. Unfortunately, these deterministic methods are insufficient in predicting the seismic motion above a few hertz. The resulting ground motion also depends drastically on the accuracy of the velocity models. Thus, most of them do not consider any amplification, due to the quaternary deposits.

To predict broadband ground motion, we used a simulation approach based on the combination of the site-specific empirical Green's function technique (EGF) and the GMPEs. We first simulated broadband seismic motion in a frequency domain of engineering interest. For that purpose, we use the empirical-stochastic EGF summation method set up by Kohrs-Sansorny et al. (2005) to generate large sets of ground motion corresponding to the target earthquake. The EGF method has the great advantage to account for the wave path in a complex medium: The simulations include the azimuth-dependent propagation effects at regional scale and account for the local $3 \mathrm{D}$ site effects under the assumption of linearity. The Mw 4.5 earthquake of February 25, 2001 is taken as an EGF to compute seismic motion that could
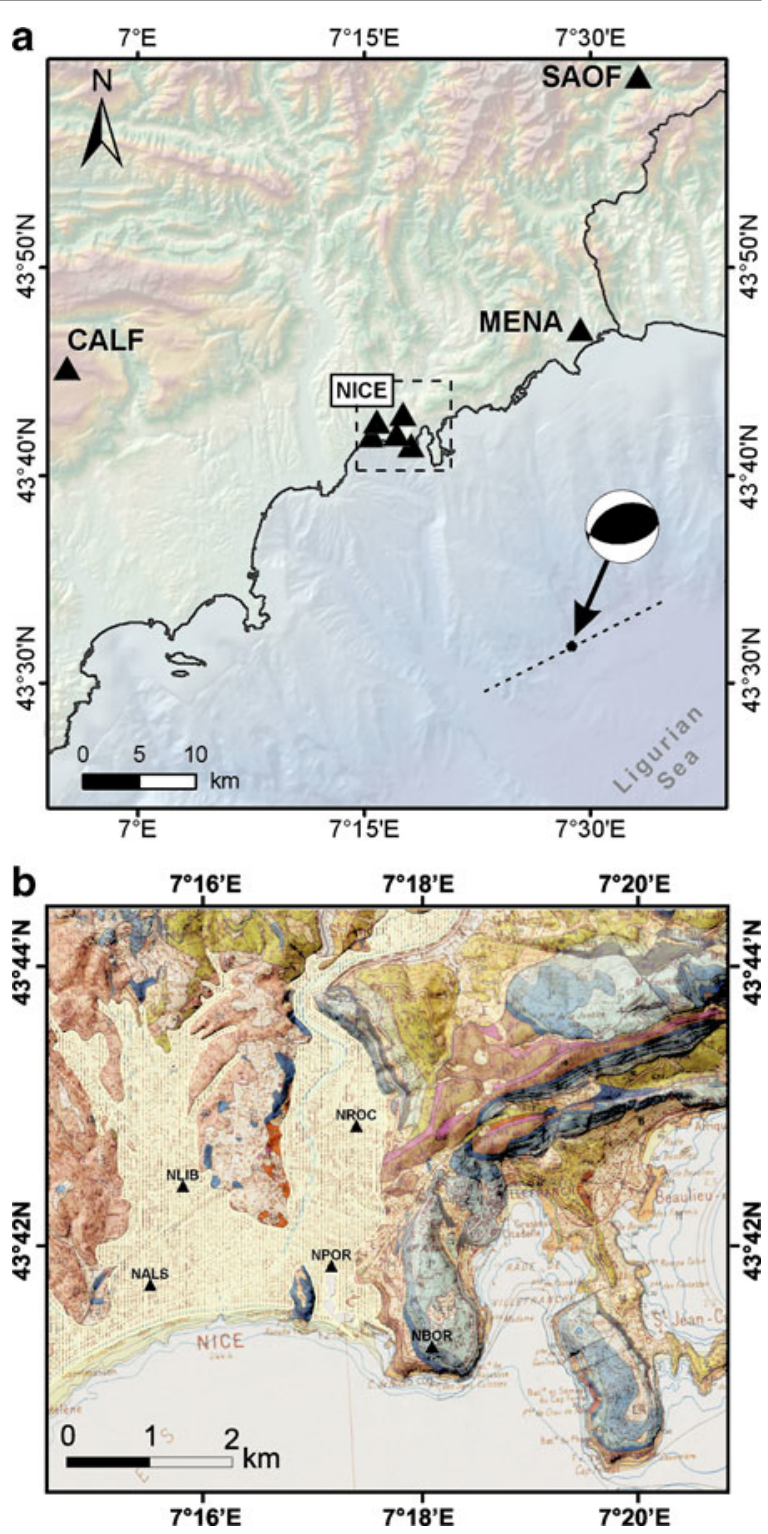

Fig. 2 a Situation map with location of the February 25th, $2001 \mathrm{Mw} 4.5$ earthquake indicated by a black dot and its focal mechanism. Dotted line indicates a hypothetical fault length of about $18 \mathrm{~km}$ long corresponding to the Mw 6.3 target event (as defined in the QSHA project). Black triangles correspond to seismic stations where the simulations are performed. Dotted box corresponds to the area shown in $\mathbf{b}$ (see legend of Fig. 1 for topography and bathymetry references). b Geological setting of the city of Nice. The quaternary alluvial deposits area where the stations NALS, NLIB, NROC, and NPOR are located are indicated by the whitened area superimposed on the geological map (BRGM map, 1:50,000). The station NBOR is located on Jurassic limestone bedrock (bluish area) 
be generated in the Nice area by an earthquake with a magnitude equivalent to the 1887 event (Mw 6.3) occurring about $25 \mathrm{~km}$ off shore, south of the city (Fig. 2). We then propose a combined use of this method with different GMPEs to calibrate our simulations. Our results are compared with the new French seismic regulation derived from the Eurocodes 8 paraseismic rules (EC8).

\section{The studied area}

\subsection{Seismotectonic context}

The junction between the southern French-Italian Alps and the Ligurian basin is one of the most seismically active areas among the western European countries. It is defined by a daily microseismicity, moderate events $(M>4.5)$ occurring about every 5 years, and a few large, destructive historical earthquakes $(M>6)$. The origin of this activity is complex and still the subject of debate. The region presents a strong topographic gradient with heights ranging from $3,000 \mathrm{~m}$ on the Argentera Alpine massif to 2,500 m under the sea level in the Ligurian basin within a short distance (about $100 \mathrm{~km}$ ). A strong structural inheritage results from a 50-My geological evolution combining different geodynamical processes such as continental collision and ocean basin opening. The convergence of the Africa plate toward Eurasia now occurs at a rate of $4-5 \mathrm{~mm} /$ year in a $\mathrm{N}$ $309 \pm 5^{\circ}$ direction at the longitude of the western Alps (Nocquet and Calais 2003; McClusky et al. 2003). This shortening is mainly accommodated along the Maghrebides (Nocquet and Calais 2004; Serpelloni et al. 2007); nevertheless, recent global positioning system (GPS) measurement shows that near $10 \%$ of this deformation is accommodated further to the north between Corsica and the Alps (Larroque et al. 2008). This shortening and the rotation of the Adriatic microplate (Calais et al. 2002) could be the main cause of seismic activity in the region, but other factors could also be important, such as the gravitational effects (body forces) caused by the presence of the Alpine massif and/or the thermomechanical effects at the continent/Ligurian ocean boundary (Béthoux et al. 2008; Larroque et al. 2008).
One of the most seismically active zones in this region is situated in the northern part of the Ligurian basin (the southern part being almost aseismic). The magnitude of the earthquakes ranging from 3.0 to 6.0 reveals inverse or strike slip solutions compatible with a compressional state of stress (Béthoux et al. 1988; Ritz 1992; Madeddu et al. 1996; Baroux et al. 2001).

\subsection{The Mw 4.5 Nice earthquake (2001)}

Two moderate size events $(M>4)$ occurred offshore at about $25 \mathrm{~km}$ toward the southwest of Nice on December 26th, 1989 (Ml 4.5) and on February 25th, 2001 ( $\mathrm{Ml} 4.6$ ). Both have been generated by the movement of a reverse fault roughly parallel to the French Riviera coastline (Béthoux et al. 1992; Courboulex et al. 2007). These events were strongly felt by the population in a large areafrom the Italian border to the city of Cannes without causing damage to construction (BCSF report 1992, 2006). They occurred offshore at the base of the continental slope. A recent bathymetric and seismic survey reveals morphotectonic features at the place of both epicenters, which could be related to an active fault (Larroque et al. 2006; Scotti et al. 2008). In Italy, tens of kilometers to the east, another structure has been detected in the area of the Ligurian earthquake (February 23, 1887).

We focus on the February 25th, 2001 event (Table 1) because it was very well recorded by seismic networks: the short period network belonging to the French seismic monitoring office ( ReNaSS) that proposed a magnitude $\mathrm{Ml}=4.6$, the broadband network (Tres Grande Resolution Sismologique), the permanent accelerometric network (RAP; Péquegnat et al. 2008), and a temporary network that was running during this period (Courboulex et al. 2007). From broadband data, Delouis (personal communication) derived a

Table 1 January 25th, 2001 event hypocenter location and focal mechanism (after Courboulex et al. 2007)

\begin{tabular}{|c|c|c|c|c|c|c|}
\hline $\begin{array}{l}\text { Latitude } \\
\text { (deg) }\end{array}$ & $\begin{array}{l}\text { Longitude } \\
\text { (deg) }\end{array}$ & $\begin{array}{l}\text { Depth } \\
(\mathrm{km})\end{array}$ & $\begin{array}{l}\text { Strike } \\
(\mathrm{deg})\end{array}$ & $\begin{array}{l}\text { Dip } \\
(\mathrm{deg})\end{array}$ & $\begin{array}{l}\text { Rake } \\
(\text { deg) }\end{array}$ & $\mathrm{Ml}$ \\
\hline 45.53 & 7.48 & 11 & 243 & 41 & 74 & 4.6 \\
\hline
\end{tabular}


moment magnitude of $\mathrm{Mw}=4.5$ using a waveform inversion method (Delouis and Legrand 1999). The maximum macroseismic intensity was reported in the coastal area to be V on the EMS98 scale. This event is the best recorded event that occurred in this area. It will be used hereafter as empirical Green functions for the simulation of a larger event.

\section{Geological setting, network, and station sites}

The city of Nice is almost entirely built on three main types of geological formation (Fig. 2). Most of the city-the city center, the old town, the Baie des Anges coast, and the western part of the city-lie on old and recent fluviatile alluvium of the Var and Paillon valleys. The alluvial plain of the Paillon consists of pebbly and silty alluvium, including some sandy layers or lenses of which location is barely known. In the southern part of the valley, these deposits can be more than $60 \mathrm{~m}$ thick (Bertrand et al. 2007).

Experimental measurements of site effects (Duval 1996) using microtremor and earthquake recordings clearly indicate that site amplifications occur in the basins of Nice. The amplification of seismic motion occurs between 1 and $2 \mathrm{~Hz}$ at the center of the alluvial filling (Semblat et al. 2000; Bard et al. 2005). Above the thickest part of the alluvial basin, the amplification factor determined by the site/reference spectral ratio computation reaches a maximum value of about 20 around a frequency of $1 \mathrm{~Hz}$ on the horizontal component. However, this resonance frequency shows a strong dependency on the thickness of the alluvial surface layers (Duval 1996; Bertrand et al. 2007), which corresponds to current theory of wave trapping in sedimentary layers.

The characteristics of this area made particularly interesting the installation of a local permanent seismological network. As part of the French RAP, five accelerometric stations have been installed in the city of Nice since 1995 (Pequegnat et al. 2008). Each accelerometric station is constituted of a strong-motion sensor (Güralp-CMG5 or Kinemetrics-Episensor), and a 24-bit three-component digitizer (AgecodagisTitan), all sampling at $125 \mathrm{~Hz}$. The time is cal- ibrated with a GPS receiver. Both the Géoazur Laboratory and the CETE Méditerranée laboratory maintain the network in southeastern France. All the data are collected and distributed by the online database (http://www-rap. obs.ujf-grenoble.fr) managed by the RAP central site in Grenoble. Thanks to the homogeneity and the quality of the data stored in the database, it gives reliable value of the peak ground acceleration recorded in case of strong events. The great sensitivity of the stations allows the detection of low-to-moderate earthquakes $(M<3)$, and simultaneously, their dynamical properties allows the recording of the ground motion produced by events of stronger magnitudes $(M>5)$ without any overflow. The main scientific objectives are increased knowledge of source effects and seismic motion, the propagation and attenuation phenomena, the analysis of site effects, and the experimental assessment of structures' vulnerability. The network in Nice is designed particularly to study site effects, as some stations are located in the alluvial basins and others on rocky sites. The number of accelerometric stations in the region of Nice is continually increasing, and in 2001, eight stations were available in Nice and its vicinity (Table 2). Stations NPOR, NROC, NLIB, and NALS are located on the quaternary filling in the city of Nice while MENA, CALF, SAOF, and NBOR are located on rock sites (Fig. 2).

Bertrand et al. (2007) proposed a 3D model of the quaternary fillings in Nice from the synthesis of all the available geological, geotechnical, and geophysical data over the city. This model is also inferred from ambient vibration recordings analysis (Bard et al. 2005; Bertrand et al. 2007). According to this model, the quaternary alluvium thickness reaches $70 \mathrm{~m}$ under NALS, $52 \mathrm{~m}$ under NROC, $45 \mathrm{~m}$ under NPOR, and $34 \mathrm{~m}$ under NLIB. The mean S-wave propagation velocity (Vs30) given under these stations by the model is equal to $235,260,250$, and $240 \mathrm{~m} \mathrm{~s}^{-1}$, respectively.

NBOR is the station that is closest to the alluvial basins of Nice. Furthermore, the site where this station is installed is characterized by a flat seismic response (Drouet 2006). Therefore, this station is often considered as a reference station for site effect studies in Nice (Duval 1996; Semblat et al. 2000). 
Table 2 Distances to the EGF hypocenter, soil types, quaternary alluvial deposit thickness, and mean S-waves propagation velocity (Vs30) of the accelerometric stations used in this study

\begin{tabular}{llllc}
\hline Stations & Distance $(\mathrm{km})$ & Soil type & $\begin{array}{l}\text { Alluvial deposit } \\
\text { thickness }(\mathrm{m})\end{array}$ & Vs30 $\left(\mathrm{m} \mathrm{s}^{-1}\right)$ \\
\hline NBOR & 25.7 & Rock & - & 1,400 \\
NPOR & 27.6 & Sediment & 45 & 250 \\
MENA & 28.3 & Rock & - & - \\
NROC & 28.4 & Sediment & 52 & 260 \\
NALS & 29.7 & Sediment & 70 & 240 \\
NLIB & 30.1 & Sediment & 34 & - \\
CALF & 63.5 & Rock & - & - \\
SAOF & 51.3 & Rock & - &
\end{tabular}

All the RAP stations in Nice recorded the Mw 4.5 February 25th, 2001 earthquake with a very good signal-to-noise ratio. In this study, we selected $70 \mathrm{~s}$ of recordings ( $10 \mathrm{~s}$ before $\mathrm{P}$ arrival) at each station as EGFs for our simulations.

\section{Method}

We aim to simulate a set of accelerograms that could be generated by an offshore Mw 6.3 earthquake at given sites of the city of Nice. In order to obtain realistic signals in a large frequency band that properly take into account path and site effects, we use an EGF approach (Hartzell 1978). The principle is to simulate the recordings of a hypothetic future earthquake using the actual recordings of a smaller one (Fig. 3). The small event recordings, indeed, contain rich information on path and site effects that could not be reproduced by a numerical modeling at high frequencies.

We chose in this work the two-step summation scheme proposed by Kohrs-Sansorny et al. (2005) and implemented in SIMULSTOC code that has the advantage in necessitating few input parameters and then allows generating in a quick computation time a large number of possible accelerograms. This method is based on the work of
Fig. 3 Schematic view of the EGF summation method. a The EGF is the waveform recorded by a small event. The source is modeled by an $\omega^{-2}$ Brune spectra. b We construct 500 different ESTFs that accounts for different rupture process for a larger event. Bottom Each ESTF is convolved by the EGF to give the 500 simulated accelerograms

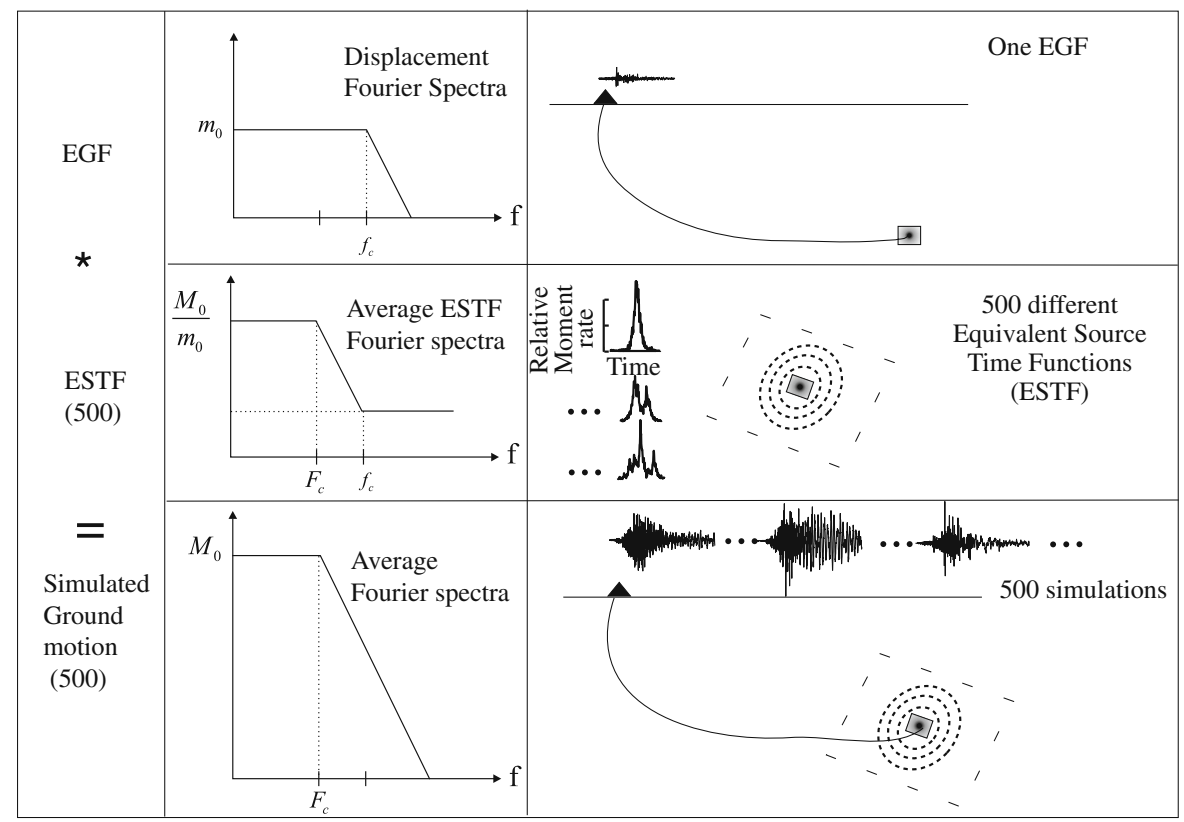


Joyner and Boore (1986), Wennerberg (1990), and Ordaz et al. (1995).

We first generate a large number (500) of equivalent source time functions (ESTFs). These ESTFs represent the time histories of the liberation of energy over the fault at frequencies lower than the corner frequency of the small event taken as EGF (Fig. 3). They are generated by a random process in two steps following two probability densities functions which shape has been proposed by Ordaz et al. (1995). The differences in the ESTF can indirectly account for different types of ruptures and produce a large variability in ground motions. This variability was recently studied by Beauval et al. (2009). We then convolve each ESTF with the EGF at each station and each component. The higher frequency part of the spectrum $\left(>f_{\mathrm{c}}\right)$ is then directly modeled by the spectrum of the small event and enables to obtain simulations at high frequency (Fig. 3).

The method produces synthetic time histories that, on average, are in agreement with the $\omega^{-2}$ model (Aki 1967; Brune 1970) and respect a nonconstant stress-drop condition (Beeler et al. 2003; Kanamori and Rivera 2004). The interest of the method is that it requires few parameters to be applied: (1) the seismic moment $\left(m_{\mathrm{o}}\right)$ and corner frequency $\left(f_{\mathrm{c}}\right)$ of the small event taken as EGF, (2) the seismic moment $\left(M_{\mathrm{o}}\right)$ of the target earthquake, and (3) the ratio $C$ between the staticstress drop of the target event $(\Delta \Sigma)$ and that of the small event $(\Delta \sigma)$.

The parameters are linked by the relationships:

$$
\begin{aligned}
M_{\mathrm{o}} / m_{\mathrm{o}} & =C N^{3}, \text { where } \\
N & =f_{\mathrm{c}} / F_{\mathrm{c}} \text { and } C=\Delta \Sigma / \Delta \sigma
\end{aligned}
$$

Note that in the SIMULSTOC code, $N$ is a scaling parameter that must be an integer. For this reason, only discrete values of $F_{\mathrm{c}}$ and $C$ can be selected. All the details of the method can be found in Kohrs-Sansorny et al. (2005).

Among the necessary input parameters, $C$ is the only one that is really difficult to define. For a practical use in the simulation, we propose further to adjust it, using the GMPEs. Note that the same ground motion simulation method has also been used recently in the objective to be included in a probabilistic seismic hazard analysis (Arroyo and Ordaz 2007; Beauval et al. 2009).

\section{Simulation of a Mw 6.3 earthquake}

\subsection{Source modeling parameters}

The February 25th event of 2001 (Mw 4.5) is taken as an empirical Green's function to simulate the target event with an inferred moment magnitude of 6.3. The inspection of the EGF data from the eight accelerometer stations gives an average corner frequency of about $1 \mathrm{~Hz}$, assuming a Brune's $\omega^{-2}$ theoretical model (Fig. 4). Determination of a relevant value of $C$ (ratio between the stress drop of the target event and the one of the small event) is a crucial point. We first present the results with $C=1$ and then propose a way to calibrate the $C$ value.

\subsection{Constant stress-drop ratio}

First, we examine the simulation under the wellused assumption of a common static stress drop for the small event and the target one $(C=1)$. Figure 5a presents the EGFs and a sample of five realizations out of the 500 generated at two stations, NALS and NBOR (N-S component). These nearby stations present different soil conditions. The strong site effect at station NALS is clearly observed on the accelerograms in terms of amplitude and duration when compared to station NBOR. The maximum amplification of the ground motion at station NALS reaches values about 10 with respect to NBOR. The aleatory shapes of the accelerograms are given by the convolution of the EGFs and the various random rupture processes (ESTFs). The simulations are also analyzed in terms of acceleration elastic response spectra (5\% damping) as it is used extensively in earthquake engineering practices (Fig. 5b). It describes the maximum response of a single degree of freedom system to particular input motion as a function of natural period and damping ratio of the system. As for the time series, we obtain various possible acceleration spectra with a large range of values. Beauval et al. (2009) checked 
Fig. 4 Fourier displacement spectra at rock-site station NBOR (three components). Dotted lines show the $\omega^{-2}$ model and the corner frequency $(0.83 \mathrm{~Hz})$ inferred for this station. Black lines indicate the average $\omega^{-2}$ model and corner frequency $(1 \mathrm{~Hz})$ deduced from the displacement spectra of the eight stations used in this study

Fig. 5 a $\mathrm{N}-\mathrm{S}$

accelerograms at station NBOR (left) and NALS (right). The recorded waveforms of the EGF are shown at the top. We present a set of five realizations at $C=1$ and their corresponding equivalent source time function $(E S T F)$. b The acceleration elastic response spectra $(5 \%$ damping) of the five simulated accelerograms at stations NBOR (left) and NALS (right)

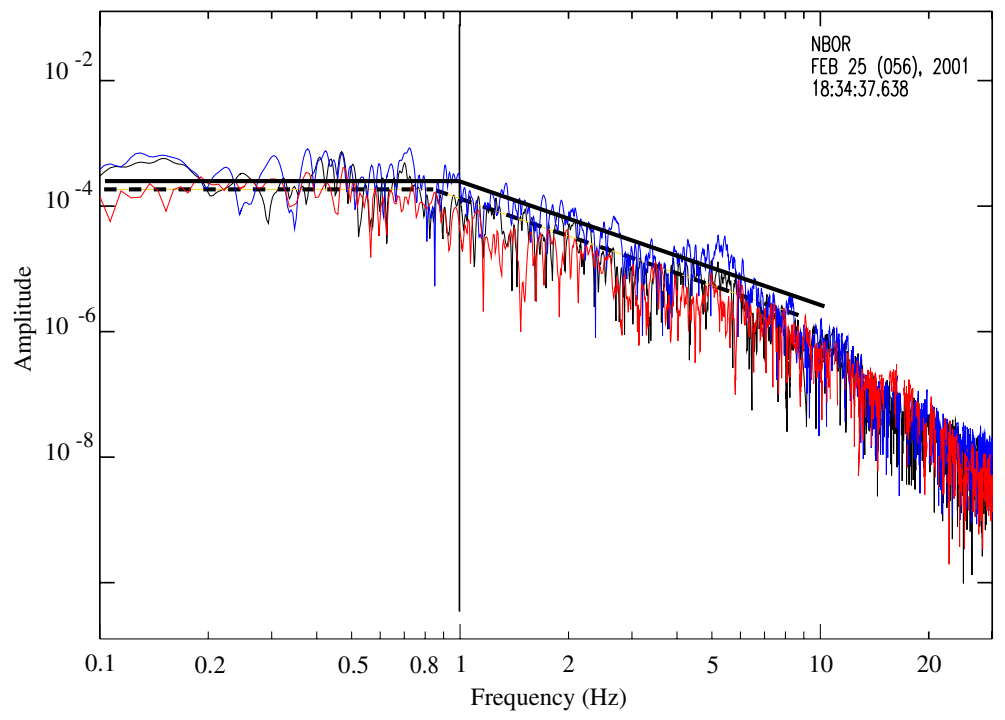

NBOR rock site NALS sediment site $\mathrm{N}-\mathrm{S}$ component N-S component
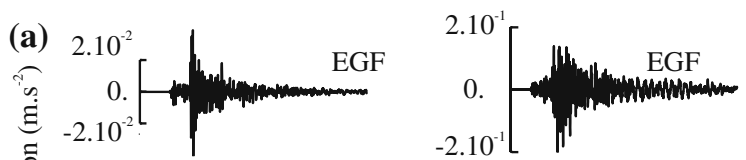

$$
\text { 莺 }
$$

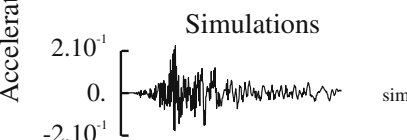

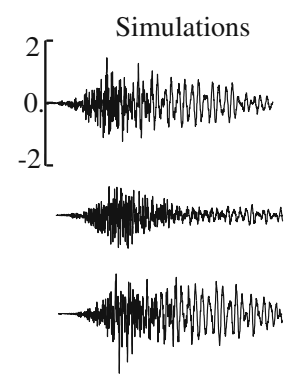

ESTF $-2.10^{-1}$
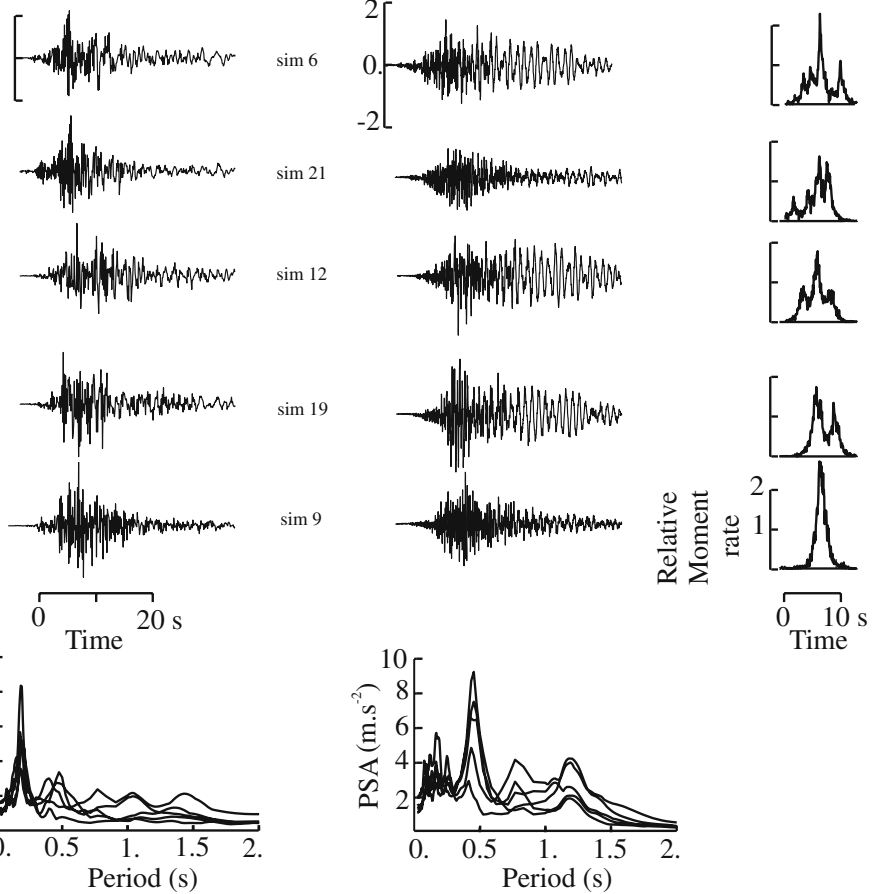

(b)

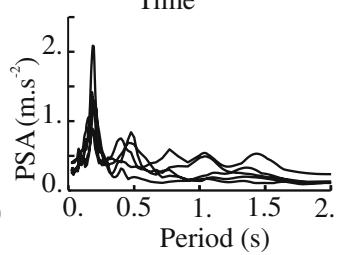


that these spectral accelerations were following a log-normal distribution. To describe our results, we simply use the mean values in log unit or the corresponding median values in the considered unit. In the same manner, we use the standard deviation (sigma) in log unit or the 16th and 84th percentiles of the realizations in the considered unit to represent the ground motion variability.

The largest spectral accelerations are found for the $\mathrm{N}-\mathrm{S}$ component, and we will refer to it in the following analysis. Figure 6 displays the response spectra of the whole accelerogram population at each station. It represents the large aleatory variability of the response spectra (light gray lines) summarized by the median (black lines) and the 16 th and 84th percentiles (dotted lines). As pre- viously observed (L. Honoré, personal communication), the percentiles show that the scattering of the response spectra is larger at sediment sites (NALS, NPOR, NROC, NLIB) than at rock sites (NBOR, CALF, MENA, SAOF). This difference is related to the larger amplitudes at high frequency in the EGFs at sediment sites combined with various source processes. The response spectra medians obtained at sediment sites clearly exhibit the local site effects. The NALS response median spectrum shows large amplitudes in the range of natural periods between 0 and $1.5 \mathrm{~s}$, whereas at NPOR and NROC, large amplitudes are seen over a range between the periods at 0 and $1 \mathrm{~s}$. NLIB exhibits lower amplitudes in the range of 0 to $0.5 \mathrm{~s}$. These results are in
Fig. 6 Acceleration response spectra curves (N-S component) for a simulation at a constant stress drop $(C=1)$. A map indicates the stations located within the Nice city. The gray lines correspond to the 500 realizations output. The black line is the median value of the realizations. The upper dotted line is the 84th percentile indicator; the lower dotted line is the 16 th percentile (e.g., $68 \%$ of the simulations are comprised between these limits)
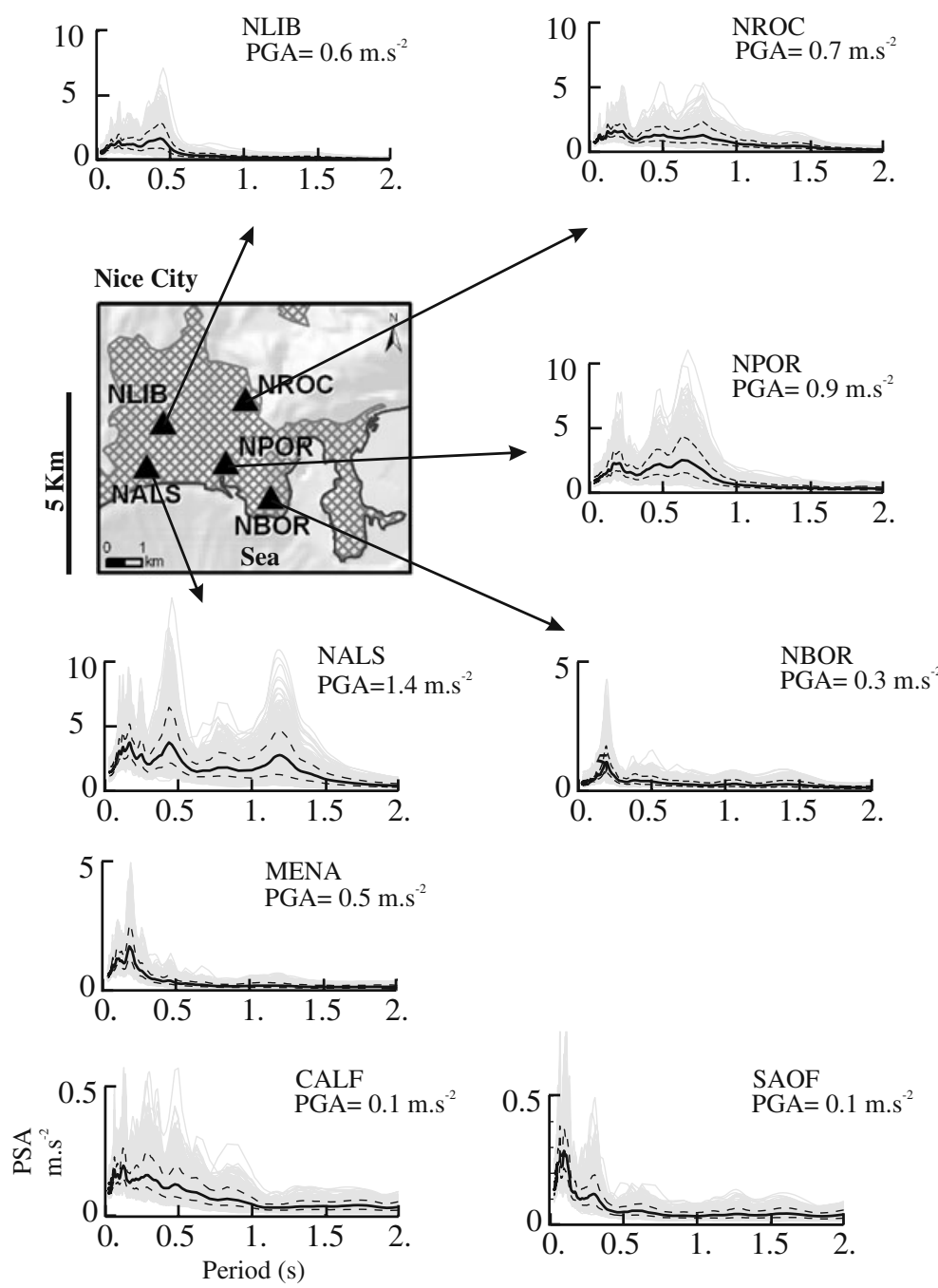
agreement with the previous site effect studies of Bard et al. (2005), Duval (1996), and Duval et al. (2001). The strongest simulated peak ground acceleration (PGA) is found at sediment site station NALS $\left(\mathrm{PGA}=1.4 \mathrm{~m} \mathrm{~s}^{-2}\right)$. Other stations located at sediment sites NPOR $\left(\mathrm{PGA}=0.9 \mathrm{~m} \mathrm{~s}^{-2}\right)$, NLIB $\left(\mathrm{PGA}=0.6 \mathrm{~m} \mathrm{~s}^{-2}\right)$, and $\mathrm{NROC}\left(\mathrm{PGA}=0.7 \mathrm{~m} \mathrm{~s}^{-2}\right)$ exhibit lower but still noticeable PGA. The stations CALF and SAOF show lower amplitudes due to their location on rock and their larger distance to the source.

The MENA spectral acceleration is found slightly larger than the spectral acceleration at NBOR, despite its further location to the source. Such amplification was observed by Drouet (2006) and could be due to the site topography or to its geological settings since this station is the only one located on Pliocene conglomerates. Another reason could be signal deamplification of the station NBOR (A.M. Duval, personal communication).

The simulation at constant stress drop is a very useful way to provide information to compare ground motion from station to station. We further complete this study focusing on the ground motion variability with stress-drop ratio changes. Indeed, in a previous study, Kohrs-Sansorny et al. (2005) showed that the adjustment of the input parameters, particularly the stress-drop ratio $C$, is essential to provide synthetic data whose frequency contents and amplitudes are compatible with observed data.

\subsection{Stress-drop ratio variation effect}

The stress-drop ratio parameter, $C$, is not a fixed parameter because we have no a priori constraints on the static stress drop of the target event. We run therefore different simulations for which the stress-drop ratio $C$ is set at different values assuming a constant seismic moment ratio $C N^{3}$ (Eq. 1), $N$ being an integer.

Table 3 presents the values we have tested between $C=1$ and $C=18.6$, which corresponds to values of the corner frequency of the target event between $F_{\mathrm{c}}=0.125 \mathrm{~Hz}$ and $F_{\mathrm{c}}=0.333 \mathrm{~Hz}$. If we assume that the total rupture duration $\operatorname{Tr} \sim 1 / F_{\mathrm{c}}$ (Hanks and McGuire 1981), this implies that we tested rupture duration from 3 to $8 \mathrm{~s}$ for the target event. This can be interpreted as earthquakes with
Table 3 Target event corner frequencies and stress-drop values inferred from Eq. 1

\begin{tabular}{lllllc}
\hline Fc (Hz) & 0.125 & 0.166 & 0.2 & 0.25 & 0.333 \\
Stress-drop ratio $C$ & 1 & 2.3 & 4 & 7.8 & 18.6 \\
\hline
\end{tabular}

increasing rupture length, or decreasing average rupture velocity, or unilateral versus bilateral rupture process.

We studied the effects of these various stressdrop ratios on the ground motion simulations. Figure 7 a shows the mean ESTF Fourier spectra for different increasing values of $C$ and then decreasing values of $F_{\mathrm{c}}$. At low frequencies $(f<$ $F_{\mathrm{c}}$ ), the spectra remain constant whatever the stress-drop parameter $C$ and stay equal to the seismic moment ratio between the small event and the target one.

At high frequencies $\left(f>f_{\mathrm{c}}\right)$, the ESTF Fourier spectra present a plateau whose level is dependent on $C$ and the scaling parameter $N$. When the ESTF is convolved with the EGF, the EGF Fourier spectra amplitudes at high frequencies above $f_{\mathrm{c}}$ are modified in a constant manner depending on $C$ and $N$ (Table 4). The resulting synthetic waveforms will then present a significant change in their high frequencies amplitudes.

The elastic response spectra (Fig. 7b) are similarly affected at low periods $\left(<1 / f_{\mathrm{c}}\right)$. We also observe that the standard deviations of the spectral acceleration distributions remain fairly constant from one stress-drop ratio to another. These sigmas seem to be frequency and site dependent as noticed by L. Honoré (personal communication). The different simulations provided here show the large high frequency range of possible ground motion obtained for a given magnitude when source properties, represented here by the static stressdrop ratio, are not constrained.

We also estimate the seismogram duration, e.g., the time interval across which $90 \%$ of the total energy is recorded (Trifunac and Brady 1975), by taking the median over the whole seismograms population. $C$ influences the seismogram duration with a decreasing signal length as $C$ increases. This decreasing duration estimation is related to the shorter duration of the ESTFs as $C$ increases (Table 4). 


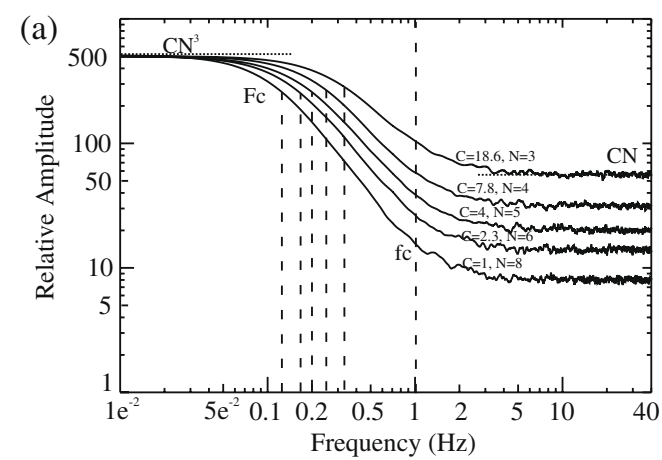

(b)
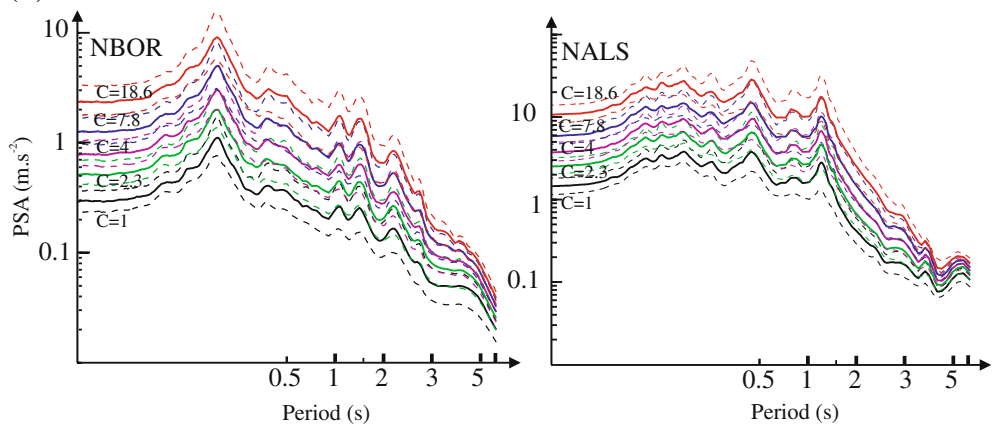

Fig. 7 Influence of stress-drop ratio parameter on the simulation outputs. a The means of the simulated Mw 6.3 ESTF Fourier spectra are shown for different $C$ values. The corner frequencies are indicated by the dotted lines. The change in the target event frequency corner $F_{\mathrm{c}}$ is indicated. At low frequency $\left(<F_{\mathrm{c}}\right)$, the frequency amplitudes remain constant and equal to the seismic moment ratio $\left(C N^{3}\right)$. At

\section{A combined EGF and EGMPEs approach}

\subsection{Calibration of the stress-drop ratio}

The simulation process applied in this paper relies on the use of the entire information content of high frequencies $\left(>f_{\mathrm{c}}\right)$, the frequency amplitudes remain constant and equal to $C N$ (Kohrs-Sansorny et al. 2005). b The median response spectra acceleration curves in the periods $0-2 \mathrm{~s}$ are shown for the $\mathrm{N}-\mathrm{S}$ component of stations NBOR (left) and NALS (right). The standard deviations (sigmas) are indicated by the dotted lines. Curves are labeled with their corresponding $C$

the EGF signal scaled to a Mw 6.3 event. As already mentioned, path, topographic, and $3 \mathrm{D}$ local site effects are included in the final results. The simulation provided in our process is thus well suited for site-specific ground motion assessment whatever the propagating medium. Nevertheless,

Table 4 Median PGA values and median seismograms duration estimated from the simulation for several $C$ values at N-S components

\begin{tabular}{llllll}
\hline & PGA $\left(\mathrm{m} \mathrm{s}^{-2}\right)$ & PGA $\left(\mathrm{m} \mathrm{s}^{-2}\right)$ & $\begin{array}{l}\text { Duration } \\
\text { NBOR (s) }\end{array}$ & $\begin{array}{l}\text { Duration } \\
\text { NALS (s) }\end{array}$ & $\begin{array}{c}f>f_{\mathrm{c}} \\
\text { amplification }\end{array}$ \\
\hline$C=1$ & NBOR & 1.4 & 21.1 & 27.1 & 1 \\
$C=2.3$ & 0.3 & 2.5 & 19.5 & 25.9 & 1.7 \\
$C=4$ & 0.5 & 3.7 & 18.8 & 25.5 & 2.5 \\
$C=7.8$ & 0.8 & 5.8 & 17.3 & 24.8 & 4 \\
$C=18.6$ & 1.3 & 10.5 & 16.7 & 24.2 & 7 \\
\hline
\end{tabular}

The mean amplification factor for the high frequency domain is also displayed with regards to accelerograms at $C=1$. The amplification factor is obtained through the ratio $C_{i} N_{i} / C_{1} N_{1}$ where $C_{1} N_{1}$ corresponds to the simulation at $C=1$ (see Eq. 1 and Table 3 ) 
we are limited by the unconstrained parameter $C$.

In order to adjust $C$, we compare the acceleration response spectra obtained with the ones described by several GMPEs taken from the literature. The GMPEs are based on ground motion recorded during past earthquakes and usually include a suite of different source mechanisms and site conditions. The GMPEs provide average ground motion parameters as a function of distance and magnitude. They are given for a defined tectonic region and a given soil class. But accounting for the precise local site specificities in the GMPEs is difficult. However, GMPEs have shown a certain accuracy to predict strong ground motion on rock site when some precautions are taken
Fig. 8 Comparison of the acceleration response spectra and GMPEs at station NBOR.

Acceleration response spectra for different $C$ are shown with thin lines (light to dark gray). GMPEs are shown with black thick lines, and the dotted lines correspond to the standard deviation (sigmas)
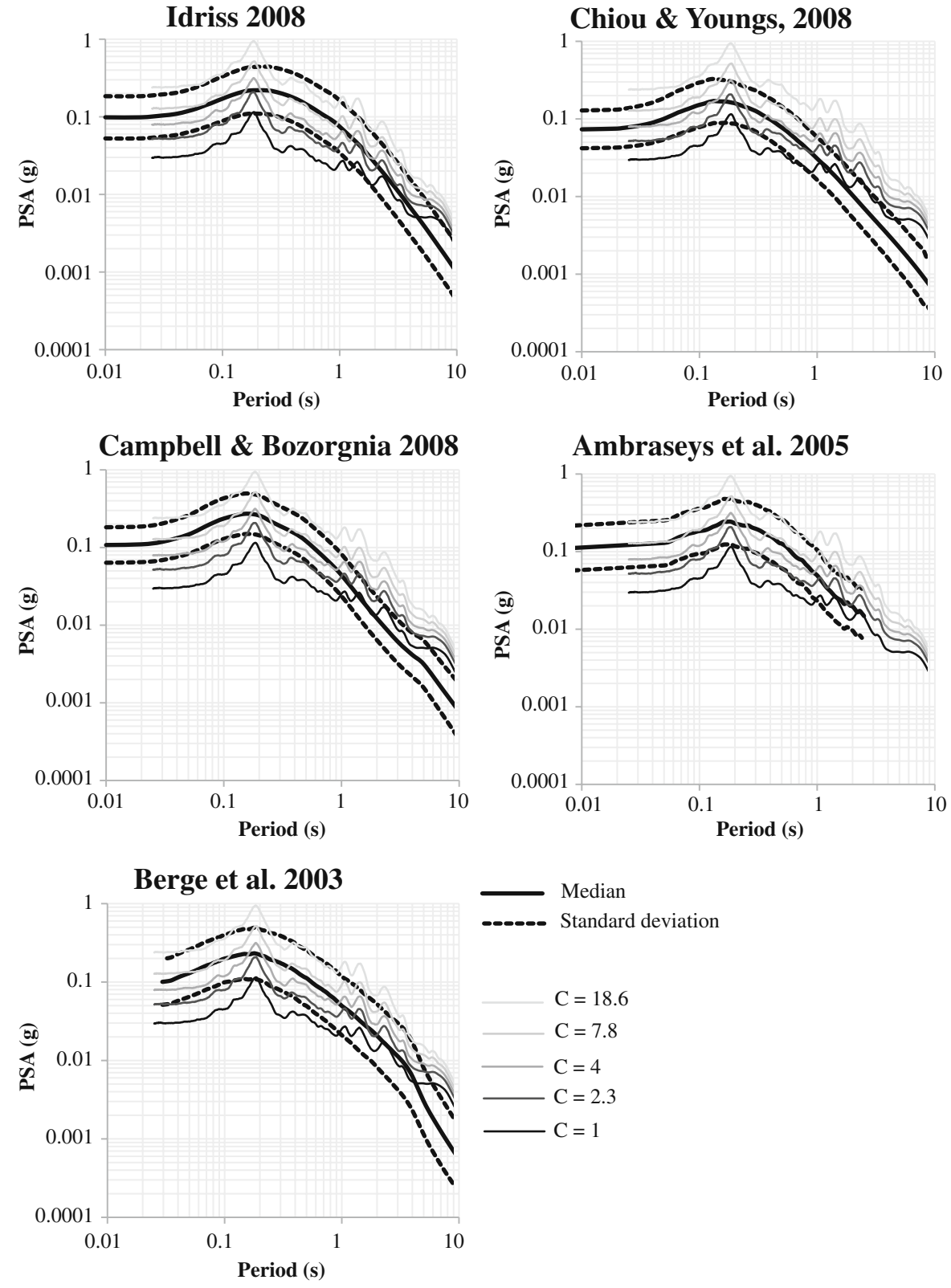
into account (Cotton et al. 2006). We therefore calibrate the parameter $C$ at the reference rock station NBOR.

In our study, we must consider GMPEs using data sets coming from other areas because the low seismic activity in France does not allow to obtain a specific empirical ground motion model. Five GMPEs are considered in order to capture the epistemic uncertainty in ground motion prediction, following Cotton et al. (2006). Three equations were built in the frame of the Next Generation Attenuation Project (Power et al. 2008; Idriss 2008; Chiou and Youngs 2008; Campbell and Bozorgnia 2008). They are derived from the same worldwide database but use a different formulation. The two others equations are mainly derived from European data (Berge-Thierry et al. 2003; Ambraseys et al. 2005). These five GMPEs meet the best criteria of relevance considered in the study of Cotton et al. (2006) such as the tectonic regime, the database used, and the date of publication. The parameters considered as input of the GMPEs are consistent with the $\mathrm{Mw}=6.3$ scenario earthquake recorded at NBOR (i.e., thrust fault, epicentral distance $R e=30 \mathrm{~km}$, Joyner-Boore distance $\mathrm{Rjb}=26 \mathrm{~km}$, hypocentral depth $h=11 \mathrm{~km}$, rock site Vs30 = $1,400 \mathrm{~m} / \mathrm{s})$.
Fig. 9 Elastic

acceleration response spectra at $C=7.8$. The response spectra acceleration medians (black lines) and the 84th and 16th percentiles (dotted lines) are presented for the $\mathrm{N}-\mathrm{S}$ component of the eight stations used in this study. A map recalls the location of the station within the city of Nice

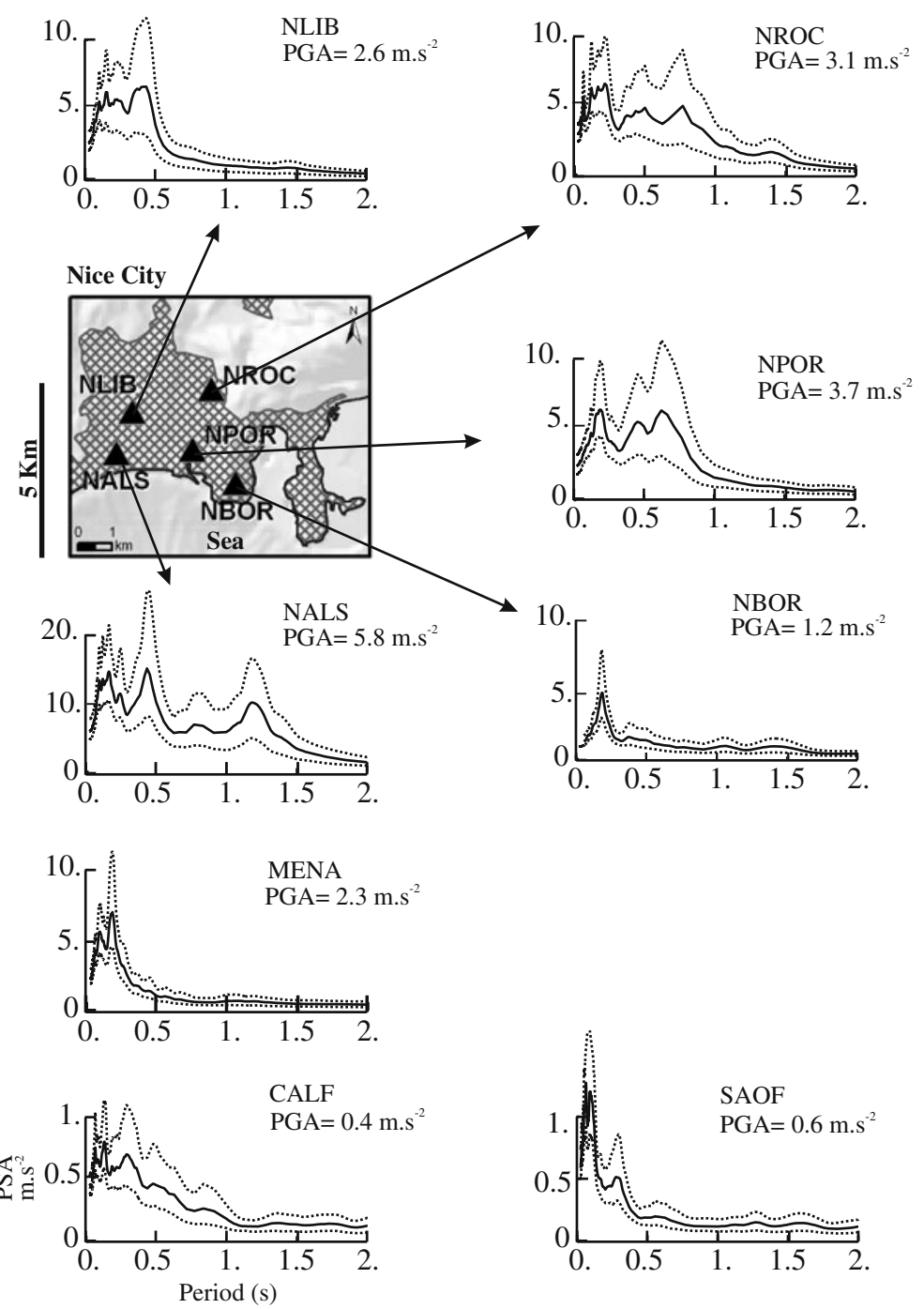


Table 5 Median PGA value for a stress-drop ratio $C=7$

\begin{tabular}{llll}
\hline & $\begin{array}{l}\text { PGA }\left(\mathrm{m} \mathrm{s}^{-2}\right) \\
\text { NS comp }\end{array}$ & $\begin{array}{l}\text { PGA }\left(\mathrm{m} \mathrm{s}^{-2}\right) \\
\text { EW comp }\end{array}$ & $\begin{array}{l}\text { Distance } \\
(\mathrm{km})\end{array}$ \\
\hline NALS(s) & $5.8(4.6 / 7.5)$ & $5.2(4.2 / 6.7)$ & 29.7 \\
NPOR(s) & $3.7(2.7 / 4.8)$ & $4(3.2 / 5.2)$ & 27.6 \\
NROC(s) & $3.1(2.5 / 3.8)$ & $2.9(2.4 / 3.6)$ & 28.4 \\
NLIB(s) & $2.6(2.1 / 3.4)$ & $2.3(1.7 / 3.1)$ & 30.1 \\
MENA(r) & $2.3(1.9 / 2.9)$ & $2.4(1.8 / 3.2)$ & 28.3 \\
NBOR(r) & $1.2(0.95 / 1.7)$ & $0.96(0.77 / 1.2)$ & 25.7 \\
SAOF(r) & $0.59(0.5 / 0.73)$ & $0.54(0.46 / 0.67)$ & 51.3 \\
CALF(r) & $0.43(0.37 / 0.52)$ & $0.36(0.31 / 0.43)$ & 63.5 \\
\hline
\end{tabular}

The 16th and 84 th percentiles are shown between brackets $(s)$ sediment sites, $(r)$ rock sites

Figure 8 shows the comparison of the spectral response between the selected GMPEs and the simulations. Though the GMPEs are scattered, we can easily exclude the simulation hypothesis of $C=1$ and $C=18.6$ that underestimates and overestimates the predicted spectral acceleration amplitudes, respectively. The simulation realized at $C=7.8$ produces the ground motion that best fit with the GMPEs set at least below the natural period of $1 \mathrm{~s}$. Above this period, the predicted spectral amplitude decreases with a greater slope than the ones from our simulations. Nevertheless, $C=7.8$ can be taken as a reference to provide constrained ground motion in our study.

\subsection{Final simulation results}

From the GMPEs comparison at the reference rock site (NBOR), we chose the ground motion corresponding to a stress-drop ratio equal to 7.8, and we consider that this calibration leads into relevant ground motion prediction to the other sites, especially those affected by local site effects. The results of the simulation of the Mw 6.3 event are summarized in Fig. 9 (N-S horizontal component response spectrum) and Table 4 (horizontal PGAs). Figure 9 shows the acceleration spectrum median, 16th and 84th percentile that we obtain at each RAP station.

The PGA is almost similar on both horizontal components of the ground motion at each station (Table 5). It ranges from about $0.4 \mathrm{~m} \mathrm{~s}^{-2}$ at station CALF to $5.8 \mathrm{~m} \mathrm{~s}^{-2}$ at station NALS located on the quaternary deposits in the center of Nice. At the reference station in Nice (NBOR), the PGA reaches a value of $1.2 \mathrm{~m} \mathrm{~s}^{-2}$. This acceleration is in good agreement with the one obtained in the RISK-UE project from the same earthquake scenario simulation (Bour et al. 2003). On the other hand, the PGAs deduced in this project from 1D site effect linear-equivalent modeling (Modaressi et al. 1997) exhibit significant smaller values in the valleys. Indeed, the maximum PGA given by the RISK-UE project reached only $1.8 \mathrm{~m} \mathrm{~s}^{-2}$, whereas in this present study, we obtain PGAs of 2.6, 3.1, 4, and $5.8 \mathrm{~m} \mathrm{~s}^{-2}$ for stations NLIB, NROC, NPOR, and NALS, respectively.

The acceleration response spectra are compared to those recommended by the French regulation (deduced from the EC8) for similar soils. According to Bertrand et al. (2007), the mean Swaves propagation velocity (Vs30) under NALS,
Fig. 10 Comparison of calibrated simulation acceleration response spectra (thin lines) to EC8 regulation (dotted lines). Left Comparison at NBOR rock site. Right Comparison at soil sites
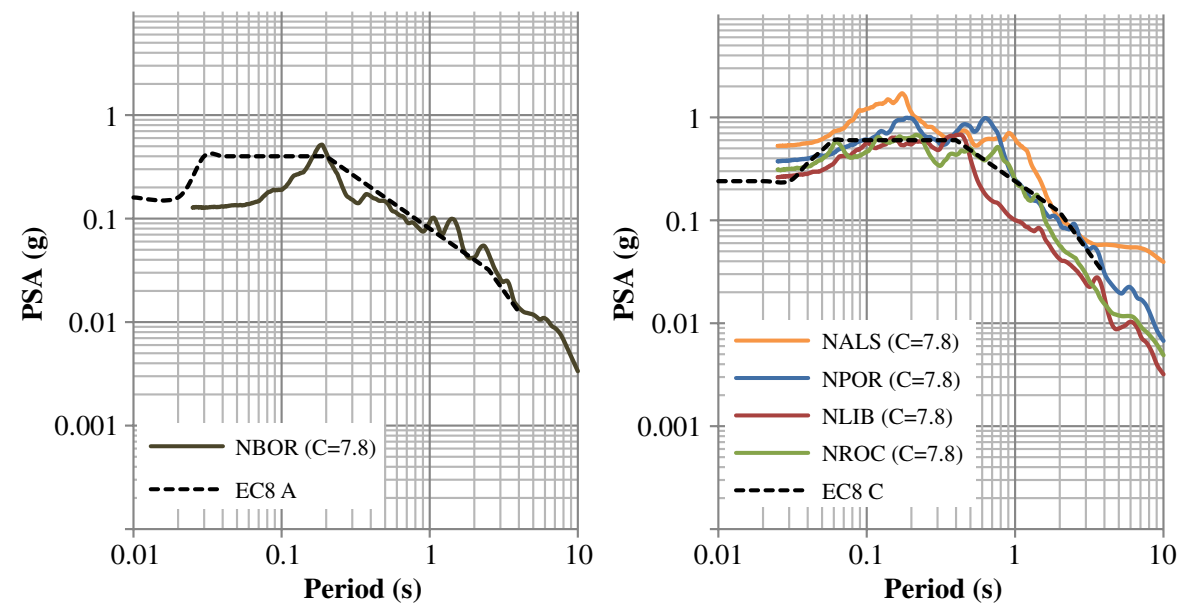
NLIB, NPOR, and NROC is characteristic of the subsoil class $C$. The associated regulatory response spectrum is shown in Fig. 10. The shape of the response spectra simulated at NBOR is concordant with the one of the EC8 spectrum at rock site even if this latter spectrum slightly underestimates the amplitude for the natural period larger than $1 \mathrm{~s}$. The simulated PGA at this station is somewhat smaller than the one prescribed for Nice in the French paraseismic rules for class II buildings - the current dwelling building. On the contrary, the PGA computed at NALS is much larger than the one taken from the regulation in Nice. At this station, the numerical response spectrum exhibits larger amplitudes than the one prescribed by the French paraseismic code over almost the whole range of natural periods. We observe the same trend for station NPOR, but for station NLIB and NROC, the EC8 class $C$ response spectra seems to be quite adapted since the simulated response spectra are below the regulatory curve. The observed discrepancy at NALS and NPOR shows that the simple Vs30 subsoil classification seems to be insufficient for describing the amplification due to local site effect. A similar statement was suggested in Bragato (2008) regarding the use of this classification in the GMPEs including site effect estimation. It also confirms that amplification due to 3D geology certainly occurs in Nice in the center of the basin quaternary fillings.

\section{Discussion}

In this part, we address some issues regarding the relevance of the results, the assumptions made, and the parameters used in the different methods.

\subsection{Nonlinearity}

The EGF method is based on the assumption of soil response linearity. We do not account for the nonlinear soil behavior triggered by sufficiently strong ground motion that is known to occur particularly in soft soil. The actual ground motion and their maxima are controlled not only by the source and the travel paths accounted for in our method but also by the limits on the strongest motion that can be transmitted to the surface by shallow geological materials. It therefore implies that the ground motions are bounded at a given site (Bommer et al. 2004). In Hartzell et al. (2002), the study of the nonlinear effects shows that the assumption of linear soil response can lead to values unrealistically high and inconsistent with observed data for earthquakes. Assessment of the nonlinear effect at sediment sites has been performed by Régnier et al. (2008) with independent linear and nonlinear methods based on the soils mechanical properties. The nonlinear effect appears to be significant only for the site NALS with possible PGA deamplification of about $2 \mathrm{~m} \mathrm{~s}^{-2}$ compared to independent linear approach. This approach is nonetheless limited by the uncertainty on the soil mechanical parameters. Therefore, the acceleration values found in our study at sediment sites should be considered as upper bound estimations of expected ground motion related to the Mw 6.3 target earthquake.

\subsection{Static stress-drop parameter}

We show that the ground motion amplitudes of our simulations depend on the inferred stressdrop ratio between the large and the small event. The static stress drop represents the only parametric uncertainty in the source characteristics that is not easily set a priori in our procedure but it is a critical parameter. As previously described by Kohrs-Sansorny et al. (2005), our approach has the advantage of not requiring the static stress drop to be scale independent. So we explored relative static stress drops between 1 to about 20 and found that a value of $C$ of about 8 gives the best fit to the a GMPEs predictions. Kanamori and Rivera (2004) suggest relative stress drops between small and large events as being in the range $1 \mathrm{e}^{-2}$ to 100 .

In this study, we only assume a magnitudeincreasing stress-drop ratio for the simulation although a magnitude-decreasing stress-drop ratio is also possible. This would allow longer equivalent source durations. Nevertheless, the simulations with $C<1$, giving low amplitude acceleration response spectra, are not in agreement 
with the GMPEs amplitudes. Thus, we only consider equivalent durations of the target earthquake ranging from $3 \mathrm{~s}(C=18.6)$ to $8 \mathrm{~s}(C=1)$. Our best choice for a static stress-drop ratio of 7.8 leads to an equivalent duration of $4 \mathrm{~s}$ implying a rather rapid energy release for a $\mathrm{Mw} 6.3$ earthquake. Nevertheless, especially in the case of a bilateral rupture process, this duration seems to be realistic.

\subsection{Far-field and point source approximations}

Our method does not account properly for the complete description of the displacement field (Eq. 4.32; Aki and Richards 1980), i.e., the nearfield terms. Nevertheless, according to Ichinose et al. (2000), given a distance of $25 \mathrm{~km}$ and a Pwave velocity of $5.8 \mathrm{~km} / \mathrm{s}$, the near-field terms contribution can be neglected for frequencies above $0.15 \mathrm{~Hz}$. Therefore, our simulations are fully valid in the frequency range of engineering interest.

The point source approximation, intrinsic in this method, does not account for the fault finiteness. Is a single small event valid enough to represent the wave path for all the points of the fault? In this simulation, we assume that this is almost true because the geometry of the faulting is parallel to the main geological and tectonic structure of the area (see Larroque et al. 2008). Therefore, the ray paths are considered identical all along the fault.

In addition, the point source approach neglects the directivity effects. The source directivity of a Mw $>6$ event can be important; nevertheless, the large variability of the ESTFs population in terms of duration and shape includes implicitly various directivity effects. In the case of our study, the fault orientation (parallel to the coast line) and the station site locations almost perpendicular to the fault strike angle present a configuration where directivity effects are limited.

\subsection{Robustness of the GMPEs}

In absence of local instrumented large earthquakes required to perform a local empirical attenuation relationship, the strong-motion simulation is constrained with GMPEs that are derived from data sets from different geographical regions. It is a strong assumption even if we reduce some epistemic uncertainty using several relationships. The simulations obtained in this study may not necessarily represent actual ground motion levels, e.g., the actual attenuation of waveforms with distance corresponding to the region and for the given magnitude. We just aimed at constraining our simulations with the more relevant available information. Nevertheless, such an approach seems to be confirmed in areas where large events are instrumented (Courboulex and Converset 2009).

\subsection{Parametrization}

Our study focuses on the influence of the stressdrop ratio parameter between a small earthquake taken as an EGF and a target event. In our method, it is the only parameter that cannot be deduced by a direct observation of the signals or inferred from the historical seismicity. Nevertheless, other parameters have an influence on the simulation such as, the EGF itself, the corner frequency of the EGF and its seismic moment (Pavic et al. 2000). Further studies should be lead to address the sensitivity of the simulation to the input parameters. Courboulex and Converset (2009) for instance compared ten EGFs used to reproduce the characteristics of the 2004, Mw 6.4, Les Saintes (Guadeloupe) earthquake.

\section{Conclusion}

The moderate seismicity, the topographic and the geologic heterogeneities of the southeastern part of France make a standard approach of the ground motion estimation rather difficult to perform using only the of GMPEs. In this study, we implement an accelerogram simulation method for a hypothetical, moderate earthquake based on the knowledge of a few parameters and on the use of a small event. It provides a population of synthetic accelerograms that can be used to estimate ground motion at instrumented sites. Nevertheless, our approach is limited by the unconstrained static stress-drop ratio between the targeted Mw 6.3 and the EGF events. In order to fix a static 
stress-drop ratio, we used GMPEs at a rock site not affected by local site effects. The comparison between the acceleration response spectra issued from the GMPEs and the simulation allows setting a stress-drop ratio parameter in agreement with all the considered empirical relationships. We thus chose a static stress-drop ratio of 7.8. Under this condition, we find that the hypothetical Mw 6.3 earthquake occurring on the same location as the February 25th, 2001 event could produce noticeable ground motion in the city of Nice, up to a median PGA value of $4 \mathrm{~m} \mathrm{~s}^{-2}$ at station NPOR for which linear behavior is still valid. Nevertheless, our results have to be considered as an upper limit of expected ground motion at the studied sediment sites since our approach is based on the assumption of the soil seismic response linearity.

The comparison of the simulated acceleration response spectra to the EC8 regulation shows that the Vs30 subsoil classification seems to be limited to describe some local site effects, especially in areas where the waveform amplification is related to complex superficial geology such as a basin. Our method has the advantage to directly account for these local specificities.

This process complements well the empirical ground motion prediction equations by accounting for the regional and 3D local site effects in the high frequency domain at any instrumented site and by providing statistically realistic waveform data sets. Finally, some improvement should be addressed by considering the nonlinearity of the soil response in the method by accounting for the site dynamic properties.

Acknowledgements We thank the persons in charge of the seismological networks stations around Nice-Didier Brunel, Christophe Maron, and Sylvain Vidal-and the persons in charge of the RAP central data management center in Grenoble. We are very grateful to Jenny Trevisan for GIS maps and Bertrand Delouis for moment magnitude determination. We benefited from the helpful scientific input of Anne Deschamps, Celine Beauval, and Laetitia Honoré. We thank Julie Régnier for her additional scientific input contributing to the validation of this study. We are grateful to Anne-Marie Duval for her relevant comments on our work. We thank the reviewers for their important and relevant remarks. This research has been supported by the French Agency of Research "ANR" through the contract ANR-05-CATT-011-03 (Quantitative Seismic Hazard Assessment project).

\section{References}

Aki K (1967) Scaling law of seismic spectrum. J Geophys Res 72:1217-1231

Aki K, Richards P (1980) Quantitative seismology: theory and methods. Freeman and Co, San Francisco

Ambraseys NN, Douglas J, Sarma SK, Smit PM (2005) Equation for the estimation of strong ground motions from shallow crustal earthquakes using data from $\mathrm{Eu}-$ rope and the Middle East: horizontal peak ground acceleration and spectral acceleration. Bull Earth Eng 3:1-53

Arroyo D, Ordaz M (2007) Inelastic-strength spectra in probabilistic seismic hazard analysis. Bull Seismol Soc Am 97(6):2171-2181

Bakun WH, Scotti O (2006) Regional intensity attenuation models for France and the estimation of magnitude and location of historical earthquakes. Geophys J Int 164:596-610

Bard P-Y, Duval A-M, Bertrand E, Vassiliadès J-F, Vidal S, Thibault C, Guyet B, Mèneroud J-P, Guéguen P, Foin P, Dunand F, BonnefoyClaudet S, Vettori G (2005) Le risque Sismique à Nice: apport méthodologique, résultats et perspectives opérationnelles. GEMGEP final report, 52 pages. www.equipement.gouv.fr/IMG/pdf/ rapportfinalgemgep-part1_cle546382.pdf

Baroux E, Béthoux N, Bellier O (2001) Analyses of the stress field in the southeastern France from earthquake focal mechanisms. Geophys J Int 145:336-348

BCSF (1992) Observations sismologiques 1989-1992. Bureau Central Sismologique Français. In French. http : // www.seisme.prd.fr/donnees /publi / 1989-1992/ obs_sismo_1989-92.pdf

BCSF (2006) Observations sismologiques 2000-2002. Bureau Central Sismologique Français. In French. http://www.seisme.prd.fr / donnees / publi / 2000 - 2002/ OBS_SISMO_2000-02ebook.pdf

Beauval C, Honoré L, Courboulex F (2009) Groundmotion variability and implementation of a probabilistic-deterministic hazard method. Bull Seismol Soc Am 99(5):2992-3002. doi:10.1785/0120080183

Beeler NM, Wong TF, Hickman SH (2003) On the expected relationships between apparent stress, static stress drop, effective shear fracture energy and seismic efficiency. Bull Seismol Soc Am 93:1381-1389

Berge-Thierry C, Cotton F, Scotti O, Griot-Pommera DA, Fukushima Y (2003) New empirical response spectral attenuation laws for moderate European earthquakes. J Earthqu Eng 7:193-222

Bertrand E, Duval A-M, Castan M, Vidal S (2007) 3D geotechnical soil model of Nice, France, inferred from seismic noise measurements, for seismic hazard assessment, paper number: NS11D-0798, American Geophysical Union Fall Meeting, San Francisco, CA, USA

Béthoux N, Cattaneo M, Delpech PY, Eva C, Réhault JP (1988) Mécanismes au foyer de séismes en mer Ligure et dans le Sud des Alpes occidentales: Résultats et interprétations. C R Acad Sci Paris 307(2):71-77 
Béthoux N, Fréchet J, Guyoton F, Thouvenot F, Cattaneo M, Eva C, Nicolas M, Granet M (1992) A closing Ligurian sea? Pure Appl Geophys 139(2):179-194

Béthoux N, Tric E, Chery J, Beslier MO (2008) Why is the Ligurian basin (Mediterranean Sea) seismogenic? Thermomechanical modeling of a reactivated passive margin. Tectonics 27:TC5011. doi:10.1029/ 2007TC002232

Bommer JJ, Abrahamson NA, Strasser FO, Pecker A, Bard PY, Bungum H, Cotton F, Faeh D, Sabetta F, Scherbaum F, Studer J (2004) The challenge of determining upper limits on earthquake ground motions. Seismol Res Lett 75:82-95

Bour M, Bertrand E, Le Brun B, Mouroux P (2003) RISK-UE WP2: seismic hazard assessment for the city of Nice. Report to the EC, EVK4-CT-2000-00014, $86 \mathrm{pp}$

Bragato PL (2008) Limits for the improvement of groundmotion relations in Europe and the Middle East by accounting for site effects. Bull Seismol Soc Am 98(4):2061-2065

Brune JN (1970) Tectonic stress and the spectra of seismic shear waves from earthquakes. J Geophys Res 75:4997-5009

Calais E, Nocquet JM, Jouanne F, Tardy M (2002) Current strain regime in the Western Alps form continuous global positioning system measurements, 1996-2001. Geology 30(7):651-654

Campbell KW, Bozorgnia Y (2008) NGA ground motion model for the geometric mean horizontal component of PGA, PGV, PGD and 5\% damped linear elastic response spectra for periods ranging from 0.01 to $10 \mathrm{~s}$. Earthq Spectra 24(1):139-172

Chiou B, Youngs RR (2008) A NGA model for the average horizontal component of peak ground motion and response spectra. Earthq Spectra 24(1):173-216

Cotton F, Scherbaum F, Bommer J, Bungum H, Sabetta F (2006) Criteria for selecting and adapting groundmotion models for specific target regions application to central Europe and rock sites. J Seismol 1:1-20. doi:10.1007/s10950-005-9006-7

Courboulex F, Converset J (2009) Ground motion simulations of a Mw 6.4 earthquake (Guadeloupe, 2004): test on 10 smaller events as empirical Green's functions. Bull Seismol Soc Am (in press)

Courboulex F, Larroque C, Deschamps A, KohrsSansorny C, Gélis C, Got JL, Charreau J, Stéphan JF, Béthoux N, Virieux J, Brunel D, Maron C, Duval AM, Perez JL, Mondielli P (2007) Seismic hazard on the French Riviera: observations, interpretations and simulations. Geophys J Int 170:387-400. doi:10.1111/j.1365-246X.2007.03456.X

Delouis B, Legrand D (1999) Focal mechanism determination and identification of the fault plane of earthquakes using only one or two near-source seismic recordings. Bull Seismol Soc Am 89:1558-1574

Douglas J (2003) Earthquake ground motion estimation using strong-motion records: a review of equations for the estimation of peak ground acceleration and response spectral ordinates. Earth-Sci Rev 61(1-2): 43-104
Drouet S (2006) Analyse des données accélèrométriques pour la caractérisation de l'aléa sismique en France métropolitaine. PhD thesis, Toulouse III, Paul Sabatier University

Duval A-M (1996) Determination of the seismic site response with microtremors. Experimental analysis (in French). PhD thesis, University Paris VI, Etudes et Recherches des LPC, GT62, LCPC, Paris, 265 pp

Duval A-M, Bard PY, Lebrun B, Lacave-Lachet C, Riepl J, Hatzfeld D (2001) H/V techniques for site response analysis: synthesis of data from various surveys. Boll Geofis Teor Appl 42:267-280

Ferrari G (1991) The 1887 Ligurian earthquake: a detailed study from contemporary scientific observations. Tectonophysics 193:131-139

Gélis C, Bonilla L-F, Régnier J, Bertrand E, Duval A-M (2008) On the use of Saenger's finite difference stencil to model 2D P-SV non linear basin response: application to Nice, France. Proceed. Seismic Risk conf., Liège, Belgique

Hanks TC, McGuire RK (1981) The character of high frequency strong ground motion. Bull Seismol Soc Am 71:2071-2095

Hartzell SH (1978) Earthquake aftershocks as Green's functions. Geophys Res Lett 5:1-4

Hartzell S, Leeds A, Frankel A, Williams RA, Odum J, Stephenson W, Silva W (2002) Simulation of broadband ground motion including nonlinear soil effects for a magnitude 6.5 earthquake on the Seattle fault, Seattle, Washington. Bull Seismol Soc Am 92:831853

Ichinose GA, Goldstein P, Rodgers AJ (2000) Relative importance of near-, intermediate- and far-field displacement terms in layered earth synthetic seismograms. Bull Seismol Soc Am 90:531-536

Idriss IM (2008) A NGA empirical model for estimating the horizontal spectral values generated by shallow crustal earthquakes. Earthq Spectra 24(1): 217-242

Joyner WB, Boore DM (1986) On simulating large earthquakes by Green's function addition of smaller earthquakes. In: Das S, Boatwright J, Scholtz CH (eds) Earthquake source mechanics, volume 37 of Maurice Ewing series 6. American Geophysical Union Monograph. American Geophysical Union, Washington, D.C., pp 269-274

Kanamori H, Rivera L (2004) Static and dynamic scaling relations for earthquakes and their implications for rupture speed and stress drop. Bull Seismol Soc Am 94:314-319

Kohrs-Sansorny C, Courboulex F, Bour M, Deschamps A (2005) A two-stage method for ground-motion simulation using stochastic summation of small earthquakes. Bull Seismol Soc Am 95:1387-1400

Lambert J, Moroni A, Stucchi M (1994) An intensity distribution for the 1564, Maritime Alps earthquake. In: Albini P, Moroni A (eds) Materials of the CEC project review of historical seismicity in Europe, vol 2. CNR, Milan, pp 143-152

Larroque C, Migeon S, Beslier MO, Mercier de Lépinay B, Sage F, Cattaneo A, Corradi N, Cuppari A, 
Marsset B, Brosolo L (2006) Aléa sismique et aléa gravitaire sur la marge nord du bassin Ligure: Résultats préliminaires de la campagne MALISAR 1. Réunion des Sciences de la Terre, Dijon 04-08 Décembre 2006, Volume des résumés p 88

Larroque C, Delouis B, Godel B, Nocquet J-M (2008) Active deformation at the southwestern Alps-Ligurian basin junction (France-Italy boundary): evidence for recent change from compression to extension in the Argentera massif. Tectonophysics 467:22-34. doi:10.1016/j.tecto.2008.12.013

Madeddu B, Béthoux N, Stéphan JF (1996) Champ de contrainte post-pliocène et déformations récentes dans les Alpes sud-occidentales. Bull Soc Géol Fr 167(6):797810

McClusky S, Reilinger R, Mahmoud S, Ben Sari D, Tealeb A (2003) GPS constraints on Africa (Nubia) and Arabia plate motions. Geophys J Int 155:126138

Modaressi H, Foerster E, Mellal A (1997) Computer-aided seismic analysis of soils. In: Proceedings of the 6th Symp. On numerical models in Geomechanics, NUMOG VI, Montréal, Quebec, Canada

Mouroux P, Bertrand E, Le Brun B, Depinois S, the RISKUE team (2004) The European RISK-UE project: an advanced approach to earthquake risk scenario. In: Proceed. 13th World Conference on Earthquake Engineering, Vancouver, BC, Canada

Nocquet JM, Calais E (2003) Crustal velocity field of western Europe from permanent GPS array solutions, 1996-2001. Geophys J Int 154:72-88

Nocquet JM, Calais E (2004) Geodetic measurements of crustal deformation in the Western Mediterranean and Europe. Pure Appl Geophys 161:661-681. doi:10.1007/s00024-003-2468-z

Ordaz M, Arboleda J, Singh SK (1995) A scheme of random summation of an empirical Green's function to estimate ground motions from future large earthquakes. Bull Seismol Soc Am 85:1635-1647

Pavic R, Koller MG, Bard PY, Lacave-Lachet C (2000) Ground motion prediction with the empirical Green's function technique: an assessment of uncertainties and confidence level. J Seismol 4:59-77
Pequegnat C, Gueguen P, Hatzfeld D, Langlais M (2008) The French Accelerometric Network (RAP) and National Data Centre (RAP-NDC). Seismol Res Lett 79(1):79-89

Power M, Chiou B, Abrahamson N, Bozorgnia Y, Shantz T, Roblee C (2008) An overview of the NGA Project. Earthq Spectra 24( $\left.\mathrm{N}^{\circ} 1\right): 3-21$

Régnier J, Bonilla L-F, Bertrand E, Duval A-M, Beauval C, Scotti O, Douglas J, Gehl P (2008) Variability of one-dimensional soil amplification estimates at four sites of the French permanent accelerometer network (RAP). In: Proceed. 14th World Conference on Earthquake Engineering, Beijing, China

Ritz JF (1992) Tectonique récente et sismotectonique des Alpes du sud: analyses en termes de contraintes. Quaternaire 3:111-124

Scotti O, Larroque C, Courboulex F, Delouis B, Baumont D (2008) On the definition of realistic earthquake parameters along potential active faults in the French-Italian Riviera: a key step in Quantitative Seismic Hazard Assessment (QSHA) a platform for strong ground motion modeling. EGU general assembly 2008. Geophys Res Abs 10:EGU2008-A-09004

Semblat JF, Duval A-M, Dangla P (2000) Numerical analysis of seismic wave amplification in Nice (France) and comparison with experiments. Soil Dyn Earthqu Eng 19:347-362

Serpelloni E, Vannucci G, Pondrelli S, Argnani A, Casula G, Anzidei M, Baldi P, Gasperini P (2007) Kinematics of the Western Africa-Eurasia plate boundary from focal mechanisms and GPS data. Geophys J Int 169(3):1180-1200. doi:10.1111/j. 1365246X.2007.03367.x

Stieltjes L, Bour M, Monge O, Martin C, Mouroux P (1996) Projet GEMITIS Nice: evaluation de l'aléa sismique local sur la ville de Nice. Rapport BRGM n R39082, 80pp, 22 fig., 9 tables, 8 pl. In French

Trifunac MD, Brady AG (1975) A study on the duration of strong earthquake ground motion. Bull Seismol Soc Am 65:581-626

Wennerberg L (1990) Stochastic summation of empirical Green's function. Bull Seismol Soc Am 80:1418-1432 